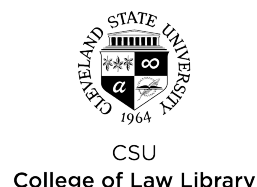

Cleveland State University

College of Law Library

\title{
EngagedScholarship@CSU
}

1987

\section{A Government By Judges: An Historical Re-View}

Michael Henry Davis

Cleveland State University, m.davis@csuohio.edu

Follow this and additional works at: https://engagedscholarship.csuohio.edu/fac_articles

Part of the Comparative and Foreign Law Commons, Courts Commons, Judges Commons, and the Jurisprudence Commons

How does access to this work benefit you? Let us know!

\section{Original Citation}

Michael Henry Davis, A Government By Judges: An Historical Re-View, 35 American Journal of Comparative Law 559 (1987)

This Article is brought to you for free and open access by the Faculty Scholarship at EngagedScholarship@CSU. It has been accepted for inclusion in Law Faculty Articles and Essays by an authorized administrator of EngagedScholarship@CSU. For more information, please contact research.services@law.csuohio.edu. 


\section{HEINONLINE}

Citation: 35 Am. J. Comp. L. 5591987

Content downloaded/printed from

HeinOnline (http://heinonline.org)

Thu Sep 27 15:49:05 2012

-- Your use of this HeinOnline PDF indicates your acceptance of HeinOnline's Terms and Conditions of the license agreement available at http://heinonline.org/HOL/License

-- The search text of this PDF is generated from uncorrected OCR text.

-- To obtain permission to use this article beyond the scope of your HeinOnline license, please use:

https://www.copyright.com/ccc/basicSearch.do?

\&operation $=$ go\&search Type $=0$

\&lastSearch $=$ simple\&all=on\&titleOrStdNo=0002-919X 


\title{
Comments
}

\section{A GOVERNMENT OF JUDGES: AN HISTORICAL RE-VIEW}

\author{
Michael H. Davis*
}

In 1921, Edouard Lambert, a professor of law at Lyon specializing in comparative studies and founder of an Institute of Comparative Law there, published a book, Le Gouvernement des juges et la lutte contre la legislation sociale aux Etats-Unis, ${ }^{1}$ thus singlehandedly creating the phrase, a "government of judges", to denote a truly unconstrained system of judicial review which could not be limited even by constitutional amendment. The phrase quickly entered the parlance of French public law and even that of popular culture, deriving much of its force, no doubt, from the historical French aversion to a strong judiciary, eventually becoming a veritable "catch-phrase". ${ }^{3}$ Over the past sixty-five years, it has acquired a diversity of meanings ranging from, most broadly, any judicial constraint upon executive or legislative action, to, most narrowly, only

* Copyright, Michael H. Davis, 1986. Professor of Law, Cleveland-Marshall College of Law, Cleveland State University, Cleveland, Ohio.

1. Le gouvernement des juges et la lutte contre la législation sociale aux EtatsUnis-L'expérience américaine du contrôle judiciaire de la constitutionnalité des lois (1921).

2. Lambert is credited by numerous writers with having introduced the phrase. "The phrase ... entered French political discourse with E. Lambert . . ." Neuborne, "Separation of Powers Review," 57 N. Y. U. L. Rev. 363, 382 n. 67 (1982). The phrase, and the various concepts it captures, reflects such a fundamental aspect of French social as well as legal culture that it has been adopted by the popular vocabulary as a shorthand way of evoking strong but ill-defined fears of judicial power. For instance, a popular journal, reporting the death of an Israeli demonstrating against Defense Minister Ariel Sharon after a judicial report found the Minister responsible for massacres in Lebanon, stated, "At the end of this tension between government by judges and that by soldiers, a death occurred," Nouvel Observateur, No. 954, p. 20, 18-24 February 1983.

3. See infra, text accompanying n. 19; Beardsley, "Constitutional Review in France," 1975 Sup. Ct. Rev. 189, 204. The historical French aversion to a strong judiciary is well-known, and it is classically traced to conditions under the Ancien Regime and its Parlements. For a treatment of the subject which more exactingly identifies that aversion as one to judicial hierarchy, and specifically as an antipathy to three analytically-separate hierarchical structures, see Davis, "The Law/Politics Distinction, the French Conseil Constitutionnel, and The U.S. Supreme Court," 34 Am. J. Comp. L. 45 (1986). 
those judicial tribunals in which judges lack sufficient professional training.

While perhaps unusual, having a central legal concept remain so loosely defined is not unknown. An American parallel is the Rule of Law. While a central concept, it remains largely undefined, ready to be marshalled in support of a wide variety of legal and political arguments. Its meaning runs the gamut from, at its broadest, simple peace and absence of illegality to, at its most narrow, the application of precedent and stare decisis. ${ }^{4}$ It would, of course, be useful to know exactly what it means when it is used. The same is true of the French concept represented by the phrase, "a government of judges". And, as it turns out, the diversity of meanings is not so mysterious at all. As this article will show, most of the meanings were a part, though not the whole, of Lambert's original argument. To define the phrase, different writers at different times have chosen different parts of the phrase's underlying argument as a response to what appeared to be the contemporary threat. Thus, the historical context tended to dictate the phrase's definition. To make matters worse, some English-speaking writers have used the phrase in apparent ignorance of its shifting meanings.

Ironically, the phrase itself has gained currency seemingly commensurately with the decline of the book's availability. It is now out of print and virtually unavailable both here ${ }^{5}$ and abroad. But though the book is unavailable, the apparently undefined phrase it bore represents such a central French concept that it is important to understand exactly what it is that the French (or we) are saying when they use (or we borrow) the phrase, and it would be interesting to know why it has acquired such a diversity of meanings.

A careful review of the literature reveals not just the meanings which have been attributed to the phrase but also a relationship, though only a rough and imperfect one, between historical developments in French legal culture and the changing meanings of the phrase. Those meanings developed contextually, paralleling developments in French legal history. In France that history includes the eventual fall of the Third Republic, the entire Vichy regime and Fourth Republic, and the first quarter-century of the Fifth; in

4. There is a fundamental distinction between " $a$ " rule of law and "the" Rule of Law. "A" rule of law simply signifies a particular legal doctrine such as a narrow ruling of the NLRB with respect to labor law. See Williamson, "Labor 'Bean Count' Skews Reagan NLRB's Record," Legal Times, p. 14, 18 Nov. 1985. "The" Rule of Law, on the other hand, has the diversity of meanings indicated in the text above.

5. There was only one edition published and it has never been translated. The RLIN and OCLC bibliographic utilities and the National Union Catalogue indicate that less than two dozen libraries in the United States possess a copy. An Englishlanguage chapter summary, hereinafter referred to as Summary, has been prepared by this author, and is on file with this journal. 
America, it extends from before the "Nine Old Men" whom Roosevelt tried to control through his court-packing plan, through the entire period of the Warren Court's liberalism, to the implementation of the Burger Court's reactionism. It is the development of the phrase within that historical context that is examined below.

A few words of caution. To observe a contextual shift of meaning in the phrase should not suggest that those changes are due to some immanent character of the phrase itself. Any conclusion based on my observations must be far more modest. What is observed is the natural tendency of people to alter their definitions in response to a changing environment, certainly not the other way around.

\section{THE BOOK}

The book is relatively straightforward, its argument supported with a rather wide range of references to then-contemporary developments in American constitutional law. ${ }^{6}$ Its point of departure, however, was a development observed starting at around 1880 at which time, Lambert claimed, judicial review shifted from mere regulation of separated public powers to judgments about the propriety of legislation. He described the Court's resistance to social legislation, notably workmen's compensation laws, labor legislation, such as that involved in the Lochner case, ${ }^{7}$ and the anti-labor construction of the antitrust laws. Lambert attributed this extension of American judicial review to the unconstrained breadth of common law generally and the American view that constitutional law was simply another species of common law.

Lambert claimed that two developments, one substantive, the other procedural, were crucial to the expansion of American judicial review. The first was the view that due process had an enforceable substantive component, resulting in the broad construction of rights to liberty, property, and contracts. Second, he wrote, American techniques of statutory construction were equally important, substituting the court's judgment for that of Congress. These two observations were supported by reference to cases and demonstrable doctrinal developments. One effect of broad judicial review, according to Lambert, was a legislative impotence which led to legislative inactivity. Not only does that lead to increased judicial power, Lambert claimed, but it creates public distrust of and hostility towards the judiciary. His most crucial and dramatic claim, however, was an undemonstrable extension of his evidence: he predicted that through the techniques of common law judging, statutory construction, and a n. 5 .

6. For a more complete review of the book's contents, see the Summary, supra

7. Lochner v. New York, 198 U.S. 45, 49 L.Ed. 937, 25 S.Ct. 539 (1905). 
substantive jurisprudence which elevated individualism above social values, judicial review could and would extend to nullification of constitutional amendments designed to limit judicial review.

To Lambert, the menace, if there was any, was that threat of judicial review of constitutional amendments. The possibility that the judiciary could control economic, social, and political growth without recourse would be threatening to any free society. It is in that sense, and only in that sense, that Lambert wrote of a "government" of judges, with the assumption that ultimate responsibility and control would lie in the judicial branch. And it was only in the fear of this threat, his extrapolation that judicial review could-and would inevitably-lead to ultimate judicial domination that one could speak of a judicially governed society.

Lambert concluded that such a situation was not just due to American conditions but also due to the inevitably conservative and ambitious nature of law and the legal profession. Thus, the same developments were possible in France if judicial review were implemented since the legal profession was essentially similar and constitutional materials, such as the Declaration of Rights of 1789, were potentially susceptible to substantive readings at least as broad as analogous American sources. He admitted that, as a result of this increased judicial activism, Americans had a more effective judicial protection of individual liberties but claimed that was due as much to history as to legal science. His conclusion was surprisingly, even laughably, modest. He suggested that French libraries collect American case materials to complement the statutory materials already available. Without such case materials, said Lambert, French scholars would have an incomplete and misleading view of the American legal system.

And so Lambert's book was not particularly controversial and was received accordingly without a stir. In fact, even today there is little with which one would seriously take issue. Except for some minor errors (in reality, nothing more than speculation), ${ }^{8}$ the only major mistake is Lambert's claim that the Court was immune to control by constitutional amendment. As an error, it was one with which all comparatists can sympathize. Just as Americans are tempted to conclude that Continental law, distinctive for its use of code sources, is judicially inflexible, so too did Lambert apparently conclude that American law, distinctive for its use of judicial common law, must inevitably be legislatively and even constitutionally impotent.

It is undoubtedly the fears that mistake may have evoked that explains the book's eventual association with various controversies.

8. See Summary, supra n. 5. 
In fact, Lambert's prediction that judicial review could extend to the propriety of constitutional amendment was treated by at least one reviewer as the reality. And it was the threat of that possibility that apparently caught the French imagination. As that early commentator said, such a development in France would lead to "stupefaction". 9 But such a stupefying threat never materialized and, as will be seen below, the phrase was employed to combat much lesser ones.

\section{The Contextual Development of the Phrase}

\section{A. Initial Reactions}

Initial reactions were balanced and mild. Reviewers understood that Lambert intended a relatively objective and non- judgmental study.

We have to choose and, at the same time, decide in favor of a traditional politics or an innovative one. The great value of a book such as Lambert's is that it facilitates this choice by clearly teaching us the results which have been achieved after a certain period of judicial control in the only major country so far which has totally adopted it. ${ }^{10}$

A book note characterized the book as "an excellent study".11 Although "the dangers of the American system are displayed with great care", it said, the book was "only an objective discussion and neither attempts to support nor to oppose any particular solution."12 A later, more comprehensive, book review was entirely favorable but, again, completely dispassionate. It admitted, as had the earlier book note, that Lambert advocated no particular position, while suggesting, however, that Lambert's preferences were not entirely disguised. On the whole, the view seems to have been that Lambert's was a helpful view of American developments from which French law could usefully profit. There was hardly a hint that the book or its theme was in any way controversial. At most, one could conclude that the book sounded a note of caution but surely not so much as to constitute a warning. In fact, in a quite ambivalent way, the choice was presented not as between good and evil, nor as between right and wrong, but instead, as between two political "tendencies", between

on one hand the conservative, traditional tendency, and, on the other hand, I don't say the progressive tendency (for if

9. Infra n.14.

10. Le Fur, "Summaries and Reviews," 29 R.D.P. 306, 314 (1922).

11. "Bulletin Bibliographique," 28 R.D.P. 445 (1921).

12. Id. 
it were a matter of certain progress, the question would not exist), but the tendency for change, the attachment to novelty. ${ }^{13}$

However, it is noteworthy that the first review read Lambert's possibility of uncontrollable judicial review to be a fait accompli. ${ }^{14}$ Further, that review noted an underlying bias beneath Lambert's neutrality, saying, "he declines to take a position, although it is easy to see the direction that he favors."15

Moreover, the phrase did not seem to these reviewers to symbolize simple judicial review, but something both more broad and more narrow: the involvement of the judiciary in social policies, in economic policies, and in the "quarrels and passions of the electoral battle". ${ }^{16}$ It must be remembered that this was occurring in the middle of the Third Republic, a time when judicial review was, although an occasional subject of discussion, nevertheless just theoretical and even, perhaps, only academic. At the time, judicial review was certainly not an important or divisive issue and what supporters it had were politically diverse. ${ }^{17}$

Ironically, but perhaps significantly, the most important article about European judicial review following the appearance of Lambert's book ignored it completely. ${ }^{18}$ Written by Hans Kelsen and appearing in an influential French review, the author, citing the example of the Austrian Supreme Court of which he was Reporter, energetically supported the notion of judicial review. Kelsen's disre-

13. Le Fur, supra n. 10 at $\mathbf{3 1 3 .}$

14. Id. at 310 :

[N]ot only has the judicial power been shown too powerful already for its powers to be effectively limited, but it is possible that it will be called to extend them even more. ...

... This is in the matter of judicial control, not just of law, but of amendments to the constitution, even the federal constitution. That is in fact the obstacle brought, in the name of the constitution, to a constitutional amendment disfavored by the judges. Such a claim would plunge our legislators and our jurists into stupefaction. In the United States it is supported by important figures and prestigious law reviews. Recently, after the 18th amendment to the federal constitution was passed prohibiting the consumption of alcohol, an appeal before the Supreme Court was brought by the liquor companies. This appeal was rejected, but for formal and procedural not substantive, reasons; the Court said nothing that would bar the possibility of acting, if need be, in a similar case.

15. Id. at $\mathbf{3 1 0 .}$

16. Id. at 311 .

17. Id. at 312:

It is because it is very logical that it has been recognized in France by so many people belonging to very different parties, from radicals or christian publicists to the progressives and partisans of new democracy.

18. Kelsen, "La Garantie Juridictionnelle de la Constitution," 45 R. Dr. Pub. 197 (1928). 
gard of Lambert's work is surprising, especially since Lambert's work has been described as

an analysis of. . .judicial review. . .which made the. . .threat of "government by judges" a menace (and a catch-phrase) to which every proponent of constitutional review in any form had therefore to respond. ${ }^{19}$

It seems remarkable that Kelsen, certainly familiar with American constitutional law, and probably also with Lambert's book, treated so sanguinely and without directly mentioning Lambert, the objections which Lambert posed. Without once using the phrase "government of judges", nor any element of the American experience, Kelsen was direct but brief. Addressing virtually all of Lambert's points, but far from finding that judicial review threatened a "government of judges", he saw in judicial review the ultimate rule of law.

Though Kelsen, like Lambert, thought it would be unacceptable were a Supreme Court to annul constitutional provisions or revisions, he, unlike Lambert, did not think that the notion of judicial review implied any such threat. He did think, though, that the use by a constitutional tribunal of general vague equitable principles, such as justice or equality, would encroach upon legislative competence. Such an event would, it can be supposed, have been thought a government of judges by Kelsen. The important difference, however, is that, despite the then recent appearance of Lambert's book, Kelsen did not think that what it predicted was in any way the inevitable result of a system of judicial review. The worst that judicial review threatened, to Kelsen, and which might therefore constitute a government of judges, was unnecessarily politicized tribunals.

\section{B. Third Republic}

It was not long before the phrase started to develop its own gloss, being applied to situations far beyond Lambert's more modest intentions. One of the earliest of these was in a note to Vincent, a Conseil d'Etat proceeding. ${ }^{20}$ In that case, the plaintiff had contested the constitutionality of legislation granting, or more accurately, delegating, legislative powers to the prime minister. He also questioned the constitutionality of self-styled "laws" decreed in accord with that parliamentary delegation, as well as the intra-ministerial regulations (arrete) issued under them. The Conseil refused to extend its review to such executive action, just as it had never acknowledged a power

19. Beardsley, supra n. 3 at 204.

20. Vincent, S. 1945, III, 53-54 (note Charlier). 
to review the constitutionality of true parliamentary legislation. The partially disapproving note, by Charlier, stated:

Classical case law guides the judge, in specifying the limits of his powers of examination, to officially provide a criterion of law to each constitutional period; our case supplies therefore the jurisprudential solution to this question which has been discussed in the last years and which remains of considerable practical interest so long as the laws of the "Vichy" remain "provisionally in force" by means of the ordinance of 9 August 1944: how does one recognize law in the "Vichy" system? ... It requires and it is enough that there is a decree issued by the chief of state in his counsel of ministers or by the chief of government in counsel of cabinet and that this decree contain the formula: "The present decree will be issued as a law of the State". Thus law is the work of the executive power, not of Parliament. It in no way issues, not even indirectly, from the people. The entire argument of the impossibility of control based upon the sovereignty of the popular will thus collapses. And the essence of the traditional textual arguments also, for the word law which appears in those former laws prohibiting control, centered upon an act having a democratic significance.

The exclusion of this control can no longer, therefore, be based upon anything other than the fear of a "government by judges", or, more precisely, of "legislation by judges", a fear ultimately leading to, technically, a limitation of the role of the reviewing judge, and an interpretation of prior laws in light of that limitation: it is no longer the object of the control that one considers, it is the possible controller. ${ }^{21}$

Used in this way, the phrase has a more general and ambiguous sense than Lambert intended. Through it, Charlier evoked the overt politicization of judicial activity which might accompany judicial review of one of the other governmental branches. Such an interpretation was necessary, however, because the dispute did not concern the legitimacy of judicial review of legislation, but, rather, of executive activity. In other words, the term was adapted to fit the historical context.

What was the significance then, to Charlier, of the phrase "government of judges"? He termed it a "fear" and implied that it was irrational, illogical and even, perhaps, unrealistic. But it signified more than the ultimately unreviewable actions of a judiciary run amok, as had been Lambert's use of the phrase. The fear was not

21. Id. 
that the Conseil would be beyond ultimate control, but that it would review something-law-which had traditionally been considered unreviewable. ${ }^{22}$ This first noteworthy use in French jurisprudence, after Lambert, of the phrase "government by judges", used it in the sense of a political involvement of the judiciary, something far short of, but thus more expansive than, the political immunity against which Lambert cautioned. In fact, Charlier understood this expansiveness, for he concluded his argument by noting, "one must be careful that this argument. . risks to go too far: pushed to the extreme it condemns all creative case law!" 23

The reason for this perversion of original intent is simply understood. The threat in Vincent was not the unconstrained judicial review examined by Lambert; to be useful, the term had to be adapted to the quite different contemporary threat of simply broader judicial latitude. This evolution introduces much later use of the phrase. It is undeniable that Lambert had mentioned the use of substantive due process review-essentially the "fear" of Vincent. But to Lambert that had been only one of the symptoms of the more profound threat of a judiciary which, exercising such review, would constitute a "government" immune to any further control rather than just one feature of a democracy. It is as if Lambert had not really created an argument, but simply supplied a device which could, and did, fulfill a pre-existing need. A carefully tempered argument fell to a long tradition of French history which would, and did, seize upon any opportunity to keep the judiciary subordinate, at any expense. In summary, the mature Third Republic view narrowed the earlier focus upon politicization of the judiciary down to only one of its components: the use by such tribunals of substantive due process review.

\section{Fourth Republic}

There was another change in the phrase and its subject during

22. Id:

Let us specify what this fear signifies. There is in the State a division of labor, and if an authority is charged with making law, it is unwise if another intervenes in this activity. But this idea should give way in the case where it is alleged that the authority charged with this activity accomplishes it wrongly and itself exceeds the limits of its division of labor in doing something else than what it is supposed to, and where the authority which intervenes only does so to return the first to the limits of its charge. To judge the legislator is not more to legislate than to judge commerce is to do that, nor than to judge crimes is to commit them! The real reason for the exclusion of this control is fundamentally, therefore, that it can be abusively detoured from its mission and to permit those who exercise it to substitute for or combine themselves with the legislators to elaborate rules according to what seems to them right and desirable.

23. Id. 
the short-lived Fourth Republic. In 1950, Roger Pinto published an article $^{24}$ examining American law. He addressed the New Deal developments, including F.D.R.'s eventually successful restructuring of the court, all of which he claimed demonstrated the demise of the phrase's underlying concept. ${ }^{25}$ There was no way that Pinto, in 1950, could foresee the developments of the Warren Court and, in an unintended illustration of the hazards of political-legal forecasting, he cited the "mediocrity"26 of Truman's nominations of Burton, Vinson and Clark, as evidence of the consolidation of the "disappearance of the left wing" of the Court. Pinto assured his readers that those nominations and the supposed right turn of the Court "will without doubt permit [Truman] to accomplish, in the future, this mission" of controlling judicial activism. ${ }^{27}$

More important, Pinto's definition of the phrase was far more unself-conscious. He seems to have equated it simply with a particular kind of judicial activism, and especially, with a specially politicized judiciary. Pinto did not suggest that the New Deal Court would have seized the kind of power that Lambert intended by the phrase, that of invalidating constitutional amendments, nor even that mentioned by Charlier: broadly substantive due process review. The issue, as Pinto correctly interpreted it, was the Court's narrow attachment to conservative economic theories in the face of the New Deal's liberal approach. Though that was certainly a part of Lambert's thesis, it was not sufficient to define it.

It is crucial to observe, then, that by the time of the Fourth Republic with its unfortunately ineffective Constitutional Committee (a product of the clearly insufficient constitutional guarantees of the Third), the simple legitimacy of a constitutional tribunal was no longer at issue. Instead, the fear the phrase triggered was not that of the tribunal itself, but of its excesses. To Pinto a government of judges referred to the "political role", or "political power"28 of the U.S. Supreme Court-prior to Roosevelt, at least-operating under what he called the "myth" of judicial neutrality. A government of judges was not threatened, according to Pinto, when constitutional judges exercised a political role, which he saw as inevitable, but only when they were insensitive to that role. One can see this, in a way, as a development initiated by Kelsen, furthered by the post-war recognition of the dangers of unbridled legislative supremacy, and ma-

24. Pinto, "The End of the Government of Judges," $66 R . D r . P u b .833$ (1950).

25. A dramatic conflict arose between Franklin D. Roosevelt and the

Supreme Court. It would put an end to the government of judges.

Pinto, supra n. 24 at 837.

26. Id. at 842 .

27. Id.

28. Id. 
tured within the experiences of the abortive Fourth Republic. But note that judicial insensitivity, too, was only one of the components of Lambert's original argument.

Although Pinto briefly echoed Lambert, observing that "the essence of the government of judges was to give to the judiciary. . .the last word," 29 he stressed that American judicial review had become reduced and simplified so that the "value judgments" which constitutional tribunals inevitably render somehow did not constitute such a "last word". By refusing to treat "economic liberalism as constitutional law", Pinto claimed, the Supreme Court avoided such a result. Pinto seems to have confused, or at least merged, substantive due process review with final, unconstrained, review. In other words, the last word was not so much in the structure of judicial review itself, which remained ${ }^{30}$ but in its political application. That is, the evil of the judicial last word was not due to the word being last but to the breadth of the word employed. Pinto had, in a way, turned Lambert on his head. In summary, Pinto accepted judicial review and even activism, but not when identified with a particular, reactionary, economic view.

The second major exploration of this theme was by Jean Rivero. ${ }^{31}$ Writing in response to Pinto's article, Rivero noted that while America was witnessing the death of its earlier government of judges, France was ironically breeding its own. The evil of a government of judges, said Rivero, as had Kelsen in portions of his article, lay in its acceptance into positive law of unwritten constitutional dogma. Rivero's targets were the "general principles of law", which the Conseil d'Etat had applied to French administrative law (there being no clear constitutional limits on the administration). The ability to "define and maintain a national ideology, and to preserve, by respecting it, the ethical foundations of the unity of the State,"32 allowed the Conseil to threaten, as did the Supreme Court, a government of judges. And, in an argument strangely reminiscent of Lambert's discussion of the Supreme Court, even the inability to override the legislature, which deprived the Conseil of the "last word", only appeared crucial, because the Conseil had declared the general principles of law to be "supra-legislative". ${ }^{33}$ Interpretation of laws could allow the general principles to pervert statutes meant to restrict the Conseil and narrow readings of others could make mere

29. Id. at 844 .

30. "Plus ça change, plus c'est la meme chose," quipped Pinto, claiming to quote an American, C. H. Pritchett. Id.

31. Rivero, "Le juge administratif francais: un juge qui gouverne?" R. Dalloz Chronique VI 6 (1951).

32. Id. at 22.

33. Id. at 23 . 
exceptions out of legislation intended to override so-called general principles.

Rivero's argument was made at a time when the Comite constitutionnel, a Fourth Republic development meant to conduct some, but only the most minimal, constitutional review, was not allowed to apply substantive standards, written or unwritten, in its deliberations. ${ }^{34}$ Thus, although it was inaccurate for Rivero to define a government of judges as the use of unwritten principles in constitutional review, it was consistent with the contemporary historical context. ${ }^{35}$

\section{Fifth Republic}

It is significant that the abuse of the phrase undoubtedly reached its high point around the time of the enactment of the 1958 Constitution. It was in part the creation of the Conseil constitutionnel that fueled much dispute and it is not surprising that the phrase was used in its broadest and least defensible sense during debate over the Conseil. Many debates over the Conseil constitutionnel derive, however unfairly, from Lambert's book and many features of the Conseil exist because of a fear of a "government of judges". In fact, there are specific provisions in the Constitution which respond to each and every one of the concerns expressed in Lambert's Le gouvernement des juges. Thus, George Bermann's claim that "constitutional review by the Conseil constitutionnel ... does not open the way to a gouvernement des juges" is paradoxical because to read the 1958 Constitution is almost to conclude that its Framers used Lambert's work as a mode d'emploi. ${ }^{36}$

The point during the drafting of the 1958 Constitution at which the phrase was explicitly employed is revealing. The Constitution, as originally proposed, only authorized review of legislation by the Conseil constitutionnel when initiated by the President, the Prime Minister, or the president of either of the two parliamentary assem-

34. See infra n. 46, however, for Rivero's later, somewhat revised views of what constitutes a government of judges, at least with respect to the Conseil constitutionnel, as opposed to the Conseil d'Etat.

35. In an illustration of how we comparatists are frequently simply wrong about jurisdictions which must always remain partly foreign to us [See Favoreu, Rapport Général Introductif, Cours Constitutionnelles Européenes et Droits Fondamentaux 26-27 (1982) and Davis, supra n. 3 at 88], Bermann has noted the irony that the French think only the American model of judicial review but not its French variant, administrative review, can threaten a government of judges. Bermann, "Comment," $27 \mathrm{Am}$. J. Comp. L. 583, 584-585 (1979). However, Bermann's claim is at odds with Rivero's twenty-five-year-old article.

36. For a discussion of the various means employed to prevent the Conseil from becoming a judicial body, see Davis, supra n. 3. Those means are, of course, traceable to historical fears dating back to the Ancien Regime in which the Parlements oppressively exercised both legislative and judicial powers. See supra n. 3. 
blies. But during the debates an amendment was offered which would have allowed such review when sought by a third of either assembly, and it was that amendment which most provoked use of the phrase.

One of the members of the Constitutional Consultative Committee suggested that this would lead to anarchy, giving to "everybody" the power of initiating review before the Conseil, which would effectively become, then, a government of "retirees". The Government representative (the Guard de Sceaux), too, agreed that the amendment could lead to a "government of judges" (but insisted that, in any event, they would not be retirees, since de Gaulle intended to appoint "active people"). Another Committee member, opposing the amendment, said that "a true constitutional court" would be synonymous with a government of judges. The author of the amendment (M. Triboulet), however, insisted that his measure only assured that an otherwise unresponsive system would offer relief to "aggrieved" parties, and therefore the proposal simply occupied a position somewhere between an ineffective tribunal and a "government of judges". 37 The amendment was adopted by the Committee but this was one of the many suggestions which were not accepted by the Government in its eventual final proposed form. ${ }^{38}$ Interestingly, however, it was almost exactly this amendment which, fifteen years later, was added to the Constitution. Many explain that this is due to the fact that the ensuing years had allowed the French to become accustomed to and comfortable with the Conseil before allowing it such expanded power. It seems that in the same way as the proposed change (and perhaps even the notion of judicial review) lost its terrifying effect, so too has the phrase gradually lost its impact. The debates over the 1958 Constitution seem to represent the high point in the use of the phrase in its broadest and most threatening sense. Since then, the phrase has encountered a more modern and knowledgeable reception.

In fact this change in the public consciousness, "a change of attitude over the traditional interpretation in France regarding Constitutional elements and declarations," is acknowledged in the remarks made twenty-four years later by the Commissaire du Government about his earlier role in the constitutional debates. ${ }^{39} \mathrm{He}$ stated that the Constitution of 1958 intentionally was silent as to the legal effect of the document's Preamble and the Rights of Man, because to do

37. Travaux Preparatoires De La Constitution, Avis et Debats Du Comite Consultatif Constitutionnel 75-76, La Documentation Francaise (1960).

38. See Beardsley, "The Constitutional Council and Constitutional Liberties in France," 20 Am. J. Comp. L. 431, 440-441 (1972).

39. Janot, in Cours Constitutionnelles Europenes et Droits Fondamentaux 212 (1982). 
otherwise "would have incited an important number of people to think that there was something that could have appeared to be a 'government of judges' ".40 Although the committee members in the 1950s could hardly have dreamed that such individual rights could ever be interpreted as binding, Janot, speaking in 1982 of that very development, observed, "one [must] consider this as progress that must be continued with wisdom (sagesse)."41

Contemporary debate over French judicial review has concentrated to a large extent over the membership of the Conseil constitutionnel. It is thus unsurprising that at least one contemporary Fifth Republic writer has defined the phrase in terms of the judges' personal predilections. ${ }^{42}$ Perhaps because many of the developments against which the phrase has been raised have become reality, a government of judges, according to Chiroux, depends upon the personalities, intentions, and institutional freedom, of those judges. Aside from occasional diatribes in the popular media, apparently the simple existence of a constitutional tribunal no longer merits the phrase's use.

According to Chiroux, a government of judges arises, as it did for Pinto, when a constitutional tribunal has "the last word" vis-avis the legislature. But what constitutes that last word is not the simple existence of such a tribunal, nor even the availability of unwritten principles as positive law. The last word is threatened when the members of a tribunal are inclined to use it as such. Limited powers and well-defined jurisdictions are constraints which prevent a constitutional tribunal from becoming a government of judges, or a Supreme Court. ${ }^{43}$ Thus, according to Chiroux, the 1974 amendments, stopping short of "autosaisine", which would have truly threatened a government of judges, were a useful advance for constitutionalism without threatening such a government. The reform, Chiroux said approvingly, was "good, but. . modest". ${ }^{4}$

Chiroux also praised the Conseil constitutionnel for its moderation and political sensitivity. Its refusal to participate in " 'law making power' ", due in large measure to the Conseil's consciousness of its low level of prestige, according to Chiroux, helps prevent it from deteriorating into a government of judges..$^{45}$ As long as the tribunal is composed of such judges, he says, neither a Supreme Court nor a government of judges can occur. While Chiroux seems favorably dis-

40. Id.

41. Id. at 213.

42. Chiroux, "Libre propos sur le Conseil Constitutionnel: Le Spectre du Government des Juges?," 868 Revue Politique \& Parlementaire 15 (1977).

43. Id. at 16.

44. Id. at 26.

45. Id. at 26. 
posed towards a Supreme Court which would protect such abstract values as constitutional democracy, and more concrete ones such as individual liberties, he concludes that the "specter" of a government of judges will prevent such a Court from developing in the near future. Possibly because a government of judges, in his eyes, was one in which the judges were unqualified or at least unequal to their task, he suggested transitional measures which would increase the prestige of the members of the Conseil.

An article written by Rivero twenty-five years after his earlier one may be an even more dramatic example of contextual meaning. For in 1975, Rivero, who had earlier defined the phrase to be the use of economic theory as constitutional law, wrote that the Conseil had been able to avoid becoming a government of judges by the exercise of its "prudence", in taking "modest" steps (reminiscent of the same words used by Chiroux), and by employing objectively ambiguous constitutional language as a limit on its own competence. In this article, Rivero asserted what constitutes a government of judges is "the substitution for the will of Parliament the will of an irresponsible group finding its own options in the elastic body of constitutional formulas. . .."46 This later discussion by Rivero of "irresponsible" members occurred at a time when one of the chief targets of critics of judicial review, and of the Conseil constitutionnel, was the allegedly political nature of the Conseil's membership.

\section{E. Specter and Catchword}

If the beginning of the Fifth Republic represents the high point in the phrase's abuse, it may reflect a growing maturity among French legal scholars that much, though not all, recent use of the phrase since then seems self-consciously exaggerated. Today, the phrase is most frequently employed to demonstrate inappropriate reactions by others to modern notions of constitutional control, implying that opponents of judicial review are reacting in an irrational and inappropriate manner. A popular textbook in France illustrates this, suggesting that the phrase evokes nothing more than a conditioned response to historical, but not contemporary, threats to democracy. According to its author, the phrase inappropriately denotes any judicial limits on absolute legislative or executive power, by unfairly employing the emotional reaction to the abuses of the Ancien Regime. ${ }^{47}$ This, of course, is an implicit recognition that earlier use

46. Rivero, "Judges Who Wish Not to Govern," in Le Conseil Constitutionnel et Les Libertés 54 (1984) (originally a note appearing in Actualité Juridique, droit administratif 134 (1975)).

47. When we speak today, in a slightly pejorative sense, of a "Government of judges," it is in reference to the time when the judiciary desired to play the role of a counterweight designed to limit royal absolutism. 
of the phrase was a distortion. American authors, though, have been slower to note this modernization. ${ }^{48}$

Contemporary French writers have also shown a more conscious recognition of the changing sense and earlier misuse of the phrase. For instance, analyzing the Supreme Court decision in I.N.S. v. Chadha ${ }^{49}$ which found the "legislative veto" unconstitutional, a Congressional attempt to assert the power to review Executive regulations, one French author observed that very few members of Congress thought the Court had "just given in to the temptation of a Government of judges." The use of the phrase seems partly sarcastic (the author immediately added, "For the most part, however, the prevailing notion was that congress had not suffered a true defeat."), especially since it equated the phrase with any, if even a minor or at least remediable, limit on Congressional power and because the author ascribed the phrase to an obviously minority position. ${ }^{50}$

This recognition that the phrase has what might be called a sarcastic contemporary utility is mirrored in a recent comment by Favoreu in which he observes that the equation of the phrase with the Supreme Court is due only to a mythical, unthinking, tradition.

For once, in France we will not turn, in matters of constitutional law, towards the American model, but towards the European model. There is, in effect, a well observed tradition in our constitutional jurisprudence which is to refer to the American Supreme Court, incarnation of all the virtues but also symbol of the famous danger or risk of the "Government of Judges." Since Lambert's book, in effect, the obligatory and quasi-exclusive reference to the "Supreme Court" has become a part of our constitutional mythology, alongside other received ideas: the American system is a good one but that system is dangerous because it leads to a "Government of judges." 51

Consistent with this modern attitude is Luchaire's knowledgeable claim that the phrase can include any and all constitutional limits in order to evoke "hostility to any control of constitutionality". 52

Perrot, Institutions Judiciaires 26 (1983).

48. Thus, Neuborne has said the phrase is a symbol of any "substantive judicial review". Though he fails to signal the changing nature of the phrase's meaning, he usefully explains its relation to the unique French legal and political experience. On the other hand, he does not identify at what point in French history the phrase had the expansive interpretation he adopts. Neuborne, "Separation of Powers Review," 57 N. Y. U. L. Rev. 363, $382(1982)$.

49. 462 U.S. 909, 103 S.Ct. 2764, 77 L.Ed.2d 317 (1983).

50. Luc Rouban, "L'Inconstitutionnalité du Veto Legislatif Aux États-Unis: Bouleversement ou Reequilibrage des Pouvoirs?," 100 R. Dr. Pub. 949, 968 (1984).

51. Favoreu, supra n. 35 at 26.

52. Luchaire, Le Conseil Constitutionnel 1 (1980). 
He treats constitutional control as a necessary evil of modern bureaucratic democracies in which popular sovereignty is increasingly smothered. He has recognized that "the specter of a Government of Judges will certainly be waved", 53 against his recommendation that the Conseil constitutionnel be made more judicial by increasing the number of jurist members. ${ }^{54}$ Luchaire's use of the phrase is in its broadest, and thus least believable, interpretation. His implied recognition that such broad use of the phrase, far from creating contemporary fears, simply unmasks unreasonable opposition, demonstrates the phrase's contextual relevance to a modern France in which "judicial review", or at least judicial constitutional control-as practiced by both the Conseil constitutionnel and the Conseil d'Etat-has been found not threatening and even acceptable.

Today, in France, it seems widely, though not unanimously, recognized that the term is nothing more than a crude synonym- perhaps with only sarcastic utility-for what Favoreu has termed, "an actor in the political arena",55 or, as one much earlier author put it, "a mine field protecting property and the individual against the government's common Program." 56 This is so whether or not Lambert originally intended it to be so, and whether or not French or English-speaking authors recognize the crudeness or blatantly political nature of the definition. ${ }^{57}$ Were it not for the fact that this use of the phrase is recognized to be myth-based, such a broader meaning might evidence much broader fears exposed by developments which must have seemed to Lambert purely and permanently academic. But instead, any persistently serious use of the term by a few in the face of that more general recognition reveals far more, I suspect, about the despair that those few might feel at the obvious changes in French public law during the last sixty years.

Some English-speaking writers have also noted the phrase's

53. Id. at 406.

54. Id. at 402 . He concludes, however:

[A] comparative study of constitutional law in the various western countries recognizing the principle of the primacy of constitutional norms would show that our Republic is, among those countries, the one which grants the least power to its constitutional judges. Now if there is one country which, by tradition, must demonstrate respect for liberty and law, it is certainly France.

Id. at 406 .

55. Favoreu, "Le Conseil constitutionnel et l'alternance," 34 R.F.S.P. 1002, 1003 (1984).

56. Luchaire, "Le Conseil constitutionnel et la protection des droits et libertés des citoyens," Mélanges Waline, Paris, LGDJ, vol. 2, at 573 (1974).

57. Favoreu, for one, obviously recognizes the inaccuracy; in fact he has said, apparently somewhat hopefully, that the French are becoming too sophisticated to use facile and inaccurate comparisons between the Conseil and the U.S. Supreme Court, aided by reference to the "mythology" of a Government of judges, when the more accurate comparison is to the other European constitutional tribunals. Favoreu, supra n. 35 at $26-27$. 
overbreadth. These writers have readily observed that the phrase has acquired in France a "traditional" rather than a technical meaning, one that simply connotes increased political importance. ${ }^{58}$ George Bermann has been even more cautious, noting that the phrase cries out for definition. It seems to be Bermann's conclusion that the myth of a government of judges is only a threat to the French when judicial activities intrude into areas which are inappropriate by virtue of history, tradition, expertise, or competence. ${ }^{59}$ Thus, review of administrative matters is accepted in France because the Conseil d'Etat has a long history and tradition of doing so whereas such review might be provocative here in the United States. Similarly, judicial review of legislation is not foreign to Americans whose federal judges frequently have personal knowledge of legislation and of political activities. French judges, being professional judicial bureaucrats, have no such expertise or competence.

Recently, especially in the summer of 1986, public use of the phrase quickened, ${ }^{60}$ as "l'alternance" of 1981-the Socialist capture of the government for the first time since 1958, and with it, of substantial nomination power over the theretofore uninterruptedly rightist Constitutional Council-developed into "la cohabitation" of 1986 - the unprecedented phenomenon of a Socialist President and a rightist government. Rightist, and some centrist and leftist, newspaper headlines trumpeted the claim of some politicians that the Council's curb upon some proposals of the new rightist majority constituted a threat to democracy, and of a government of judges ${ }^{61}$

It seems surprisingly late in the constitutional day for such use of the phrase and it is difficult to reconcile with the advances made in recent French constitutional law. But if one proceeds from the headlines to the text, one notes that the criticism was not aimed, as the headlines would have implied, at the simple interference by the Council with the immediate and complete implementation of the

58. The committee which drew up the first draft of the constitution in 1958 had proposed that recourse should be open to one third of the members of either House, but the Government of the day, realizing that this would greatly increase the political importance of the Conseil, and responding to the traditional fear of "government of judges", had adamantly opposed it.

Nicholas, "Fundamental Rights and Judicial Review in France," Part II, 1978 Pub. L. 155; citing Favoreu, "Le Conseil constitutionnel regulateur de l'activite des pouvoirs publics," 83 R. Dr. Pub. 1967, 5, 97.

59. Bermann, supra n. 35 at 584-585.

60. See, for instance, Kajman, "Le conseil constitutionnel estime que la nouvelle loi sur la presse ne garantit pas le respect du pluralisme," Le Monde, p. 5, 31 July 1986; Fontaine, "Pluralisme," Le Monde, p. 6-7, 1 August 1986; Societé, Le Monde, p. 6, 9 August 1986; Portelli "La partitocratie triomphante," Le Monde, 29 August 1986.

61. "J.J. Queyranne (PS): 'Non au Gouvernment des Juges' " La Croix, 9 November 1984; Duhamel, "Le parlement des juges," Le Monde, 19 July 1986; "Le Conseil constitutionnel, guardien de la Constitution ou gouvernment des juges?" Le Quotidien, 17 October 1986. 
majority's projects. In fact, the comments were notable for two factors: first, there was virtually unanimous agreement that the existence of the Council was necessary and important to a modern democracy, and did not alone constitute the forbidden government of judges ${ }^{62}$; second, the criticisms were specifically directed at the Council's reasoning and its use of principles that did not explicitly appear in the Constitution. The predominant demand was simply that the Council should limit itself to the Constitution's "table de lois", that is, its explicit mandates. ${ }^{63}$

Most notable in the censure was an approach remarkably similar to that found in American legal criticism. Just as critics of such decisions as Roe $v$. Wade, for instance, challenge what they perceive to be illegitimate judicial legislation, the French critics, with their reference to the "Tablets of the Law", insist that the Council should be confined to the literal text of their Constitution. ${ }^{64}$ It seems that, at least by the summer of 1986 , what constitutes a government of judges is similar to that found unacceptable by discontented Americans as well: the exercise of something akin to "substantive due process". Within such a specific critique, however, is the implicit acceptance of the principle of constitutional adjudication as legitimate, necessary, and even democratic. This is rather amazing within the context of French constitutional law and its development in less than thirty years is or should be encouraging to its supporters. It seems quite obvious that the phrase does not today connote what it did more than half a century ago. If, as the most recent debates suggest, the phrase is now limited to the particular method of legal reasoning we call substantive due process, then the phrase has no distinctively French sense. It no longer implies that the French generally reject constitutional adjudication.

However, while most modern French authors and some Englishspeaking ones have thus abandoned their formerly crude use of the phrase, it is perhaps not altogether surprising that many American

62. E.g., the Garde des Sceaux, Albin Chalandon, Minister of Justice in Chirac's rightist government, admitted that "There are no problems today even if each time a law is enacted, the first question that arises is to know whether it will pass the Constitutional Council. . . . I have suggested self discipline by the Council itself. Le Monde, p. 7, October 1986. The Left as well, who were once its most vocal critics now are sanguine about the reality of constitutional adjudication, and criticize not its existence but its direction. "The Constitution of 1958, by creating constitutional contral in the image of other great western democracies, was a step towards the Rule of Law. But the erosion to which we are now witness is dangerous. It could carry us towards a government of judges." Jean-Jack Queyranne, National Secretary, Socialist Party, in La Croix, 9 November 1984.

63. "Instead of relying upon the Tablets of the Law, being the Given Commandments, the Constitutional Council relies instead upon general principles. By this, it has a discretionary power." Albin Chalandon, Garde de Sceaux, Minister of Justice, Le Monde, p.6, 9 August 1986. See, also, "Le Figaro," 18 October 1986.

64. Supra n. 63. 
authors nevertheless maintain the ambiguous sense of the phrase and with it a particular American view of French public law. Thus, several recent American writers persist in equating the phrase with judicial review. ${ }^{65}$ Not only that, but, in Canada the phrase has been used in discussing, of all things, English review of administrative decisions!66 If the French have modernized their use of the phrase because of a growing comfort with the notion of enlarged constitutional control, some American writers cannot seem to accept or at least recognize that development. It seems ironic, in fact, that many Americans insist on remaining attached to an outdated view of French constitutional law as something slightly quaint.

\section{CONCLUSIONS}

Initial reviews of Lambert's book and its thesis treated it as a call to reasoned consideration; but soon some French writers began to use the phrase as a call to arms, as a warning against any consideration of reforms far less threatening than those that Lambert addressed. Why this reception changed is entirely speculative. However, the underlying facts are not. The observations Lambert made were actually, though perhaps not intended to be, preliminary. He described a dynamic, rather than static, situation. Even as Lambert wrote there was movement away from the doctrines he observed; the very precedents upon which change would be based were being decided as he wrote. Thus, his observations could justifiably only be treated as tentative and perhaps Lambert intended no more. To be useful to later writers in need of a slogan, however, the phrase could not be hedged by caveats and distinctions. Sloganeers therefore have used the phrase in a partial manner--to attack selectively one of the many objects of Lambert's argument-without taking the time (and thus losing impact) to qualify the citation.

What is especially marked in the contrast between Lambert's own position, as well as its initial reception, and those who later employed it to their own ends is the basis for their arguments. It is striking that to Lambert and his contemporary readers the choice between a government of judges and one of legislators was not a principled one, not a functional one, not even an institutional one; it was, rather, a prudential one. In fact, the choice was essentially be-

65. Neuborne, supra n. 48 at 382 . Beardsley, supra n. 3 at 204-06, 256. The most recent use of the phrase by an American seems to be in Keeler, "Confrontations juridico-politiques: le Conseil constitutionnel face au Government socialiste comparé à la Cour suprème face au New Deal," 35 Pouvoirs 133, 134, 146 (1985) (also published in French Politics and Society, October 1985).

66. Brown \& McNicoll, "Le juge: censeur de l'Action de l'Administration," 25 Cahiers de Droit 451, 451, 460-1 (1984). This is perhaps not all that strange. It is nothing less than Rivero's 1951 argument transported to Canada and England. 
tween two personality types. It was not dominated by a law/politics distinction but by a lawyer/politician one. One might even say that it was a choice between law schools and political science departments. It was a choice between tradition and change, between conservatives and progressives. As the first published book note observed, the choice dramatized by Lambert's work did not involve political institutions but simply professional training.

The decisive question is therefore this: from which milieu should those who will exercise supreme control in a country be chosen, what should their social training be? Should they be exclusively jurists, or politicians? Because there is a marked difference between them. A traditionalist bent is much more prominent for the former than for the latter. ${ }^{67}$

And it may be the subsequent historical context, and its lack of any reasonable probability that judicial review along American lines could develop, that explains the later different reactions.

Once again, a note of caution. If the meaning of the phrase has been altered, that must be due to French, and perhaps even American, constitutional developments. To think that the phrase, or Lambert himself, had the power or foresight to effect such changes on their own is to claim an exaggerated importance for authors and their words which it ill-behooves us to do.

I could conclude, similar to Lambert, 68 that the reason his phrase was abused is simply that his book, like the dearth of case materials he bemoaned, is unavailable. But surely scholars on both sides of the Atlantic, even if they have not had enough materials to satisfy their wants, have had more than enough sense to avoid the utterly crude abuse the phrase has suffered. It was not a failure to read, but a failure to consider and reflect. Even de Gaulle, surely no constitutional scholar, recognized the difference between the threat of a government of judges and the Conseil constitutionnel. ${ }^{99}$ There will be and always has been a long way to go, an unlikely way, in France and the United States, before that threat becomes worthy of concern. It may be speculative to wonder whether the phrase's history makes any difference. But of all the speculations, the one with the most concrete consequences is whether, at the time the 1958 Constitution was being drafted, a more explicit comprehension of the phrase and a more knowledgeable understanding of its history could have avoided the use (and abuse) of the phrase to limit, per-

67. LeFur, supra n. 10 at 313 .

68. See Summary, supra n. 5.

69. Charles de Gaulle, Press Conference, 31 January 1964, documents d'étudesDroit Constitutionnel et Institutions Politiques 31-32 (George Burdeau, ed. 1976). 
haps unduly, the powers of the Conseil constitutionnel. Whether the kind of academic license demonstrated by the history of the phrase is thus responsible for stunting twenty years of French constitutional history is certainly worth pondering. 